\title{
Squirrel monkeys in Costa Rica: drifting to extinction
}

\author{
Sue Boinski, Katharine Jack, Craig Lamarsh and Jessica A. Coltrane
}

\begin{abstract}
Central American squirrel monkeys Saimiri oerstedii are limited to Costa Rica and Panama, and have never been abundant. The Costa Rican population is now decimated. Based on our survey of squirrel monkeys throughout a large portion of the Costa Rican range of this species in 1996, we can confirm that at least 1246 squirrel monkeys remain in 26 spatially dispersed localities. Despite probable undercounts of squirrel monkeys within sites and potentially missed localities, the total population size should be considered far below a size that would provide longterm genetic viability. Deforestation and habitat fragmentation spurred by agricultural and tourism development are the familiar culprits contributing to this decline. Our strong recommendation is that future conservation efforts be targeted at the level of each specific locality, perhaps recruiting local, national and international sponsors. A focused strategy would allow management efforts to be tailored to the circumstances specific to each site and thus allocate scarce resources more efficiently.
\end{abstract}

\section{Introduction}

'Drifting' in the sense 'to move or be carried in a casual, unimpeded manner' is, unfortunately, an appropriate term to describe the progression of Central American squirrel monkeys in Costa Rica, Saimiri oerstedii oerstedii and S. o.citrinellus, towards extinction. Historical records indicate that the distribution of this species has always been restricted to the Pacific wet lowlands of Costa Rica and Panama, an area of less than 8000 sq $\mathrm{km}$, and $600-1000 \mathrm{~km}$ from the nearest South American squirrel monkeys (Hershkovitz, 1984). The urgent need for conservation measures has been emphasized relatively recently (Boinski, 1985, 1987a; Wong et al., 1994). In 1983 the number of squirrel monkeys in Costa Rica was estimated at 200,000 based on informant interviews (Vaughan, 1983). Currently Saimiri oerstedii oerstedii (Figure 1) is listed as Endangered while S. o. citrinellus (Figure 2) is listed as Critically Endangered (Rylands et al., 1995; Rodriguez-Luna et al., 1996, IUCN, 1996). Populations of these two

(C) $1998 \mathrm{FFI}$, Oryx $32(1), 45-58$ subspecies were most recently estimated at $c$. 3000 and 500-1000, respectively (Boinski and Sirot, 1997). Concomitant with this steep decline in the estimated population of squirrel monkeys was a massive increase in the rate and absolute amount of deforestation and forest fragmentation in Costa Rica (Butterfield, 1994). Squirrel monkeys in Panama (only the S. o. oerstedii subspecies) have fared even worse. For more than a decade Panamanian wildlife biologists thought that squirrel monkeys in their country were extinct as a result of massive deforestation (Boinski and Sirot, 1997). In 1996, however, a small population ( $<25$ individuals) was discovered in a 70-ha reserve on the Pacific coast at $\mathrm{La}$ Barqueta $\left(8^{\circ} 23^{\prime} \mathrm{N}, 82^{\circ} 36^{\prime} \mathrm{E}\right.$; R. Samudio, pers. comm.).

One of the notable features of squirrel monkey conservation in Costa Rica has been the lack of detailed documentation of the surviving populations. The few surveys reported thus far have either relied exclusively on interviews with local inhabitants (Vaughan, 1983), censuses focused on highly restricted 


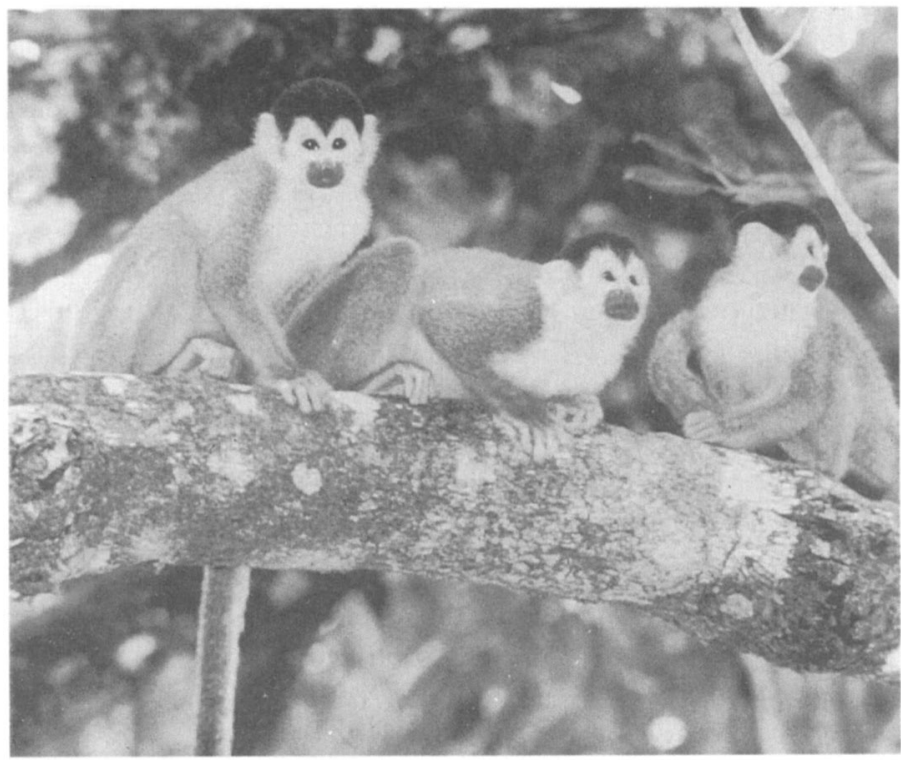

Figure 1. Three juvenile male $S$ o. oerstedii, each approximately 2.5 years old (Craig Lamarsh). geographic areas (Wong, 1990a; Arauz, 1993), or fieldwork in restricted areas combined with information provided by biologists with knowledge of other regions (Boinski, 1985, 1987a; Boinski and Sirot, 1997). The lack of accurate data has probably hindered restoration or stabilization of squirrel monkey numbers. For example, two recent international workshops devising management strategies for S. $o$. citrinellus relied heavily on VORTEX Population Viability Analysis (PVA) models (Wong et al., 1994; Matamoros et al., 1996). Yet the accuracy of PVA models is constrained by the quality of the data on which they are based (Lacy, 1993), and the population estimates used in these PVAs are inflated relative to more recent surveys (Boinski and Sirot, 1997).

In 1996 we conducted the most extensive survey to date of squirrel monkeys in Costa Rica, encompassing the range of S. o. oerstedii and much of the range of S. o. citrinellus. The purpose of this report is to present distribution data for these two subspecies, evaluate current threats to their survival, and recommend appropriate management strategies. In addition, we suggest that $S$. oerstedii provides a useful case study of the effectiveness of conservation efforts confronting pressures for development. Costa Rica is arguably among the countries of Central and South America with the greatest conservation sophistication (Fundación Ambio, 1993; Reid et al., 1994), and the largest proportion of land reasonably protected in national parks, reserves, and wildlife refuges (11 per cent; Carrillo and Vaughan, 1993). Furthermore, tourism, much of it generated by Costa Rica's scenery and wild life, is its single largest source of foreign currency. The Instituto Costarricense de Tourismo (ICT) estimates that in 1996 alone over \$US1 billion was generated by 800,000 foreign tourists in Costa Rica (ICT, unpubl. data). If an appealing monkey can become extinct or closely approach extinction here, what are the realistic prospects for effective species conservation elsewhere?

\section{Natural history}

Owing to arguments that squirrel monkeys were probably first introduced into Central America from South America by prehispanic Amerind traders (Hershkovitz, 1984), the merit of conservation efforts has been somewhat clouded and suspect. Why bother with an 'introduced' species when so many indigenous species are at risk? Convincing

(C) $1998 \mathrm{FFI}$, Oryx 32 (1), 45-58 
Figure 2. A fully mature adult male S. o. citrinellus (Sue Boinski).

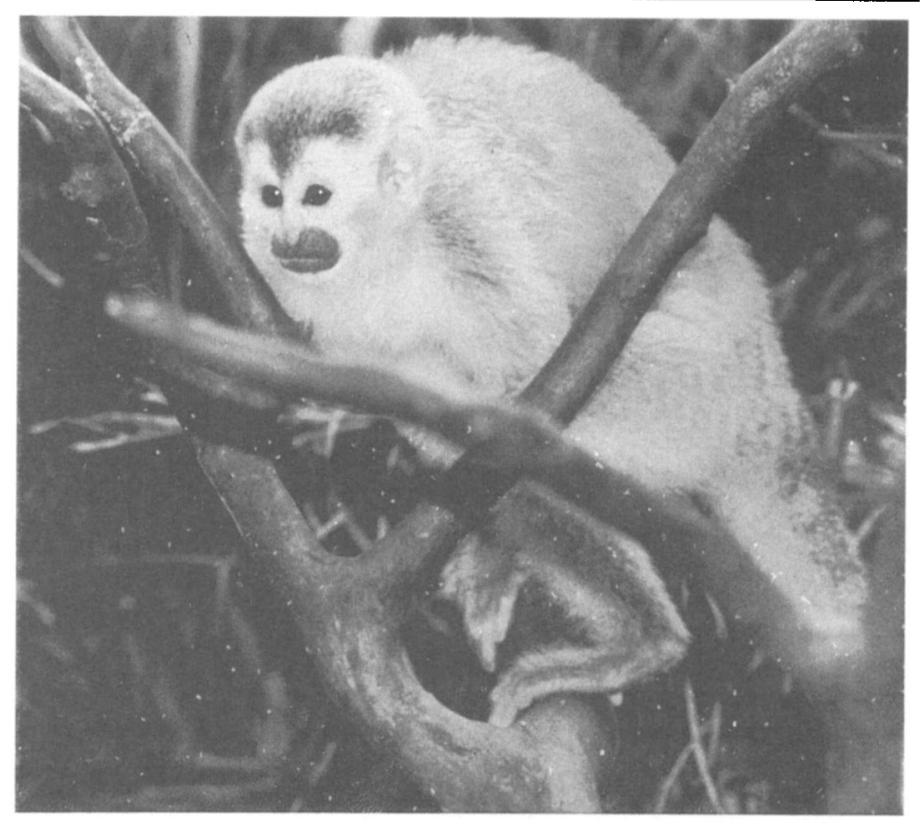

evidence now exists that $S$. oerstedii was present in Central America prior to the arrival of humans, and is distinguished from squirrel monkeys in South America in numerous respects. First, cladistic analyses based on extensive mtDNA sequence data from hair follicle collections from squirrel monkeys of known geographic origin in Costa Rica (S. o. oerstedit and S. o.citrinellus), Guyana and Suriname (Saimiri sciureus sciureus), and Peru (S. s.boliviensis) found that approximately the same degree of sequence divergence exists among the three clades, and that the divergence is likely to be ancient (> 500,000 years; Boinski and Jacobs, 1997). Second, detailed comparisons of the morphology and enzyme banding patterns of $S$. oerstedii and South American squirrel monkeys indicate greater differences between the two geographic areas than are found within South American populations (Costello et al., 1993). Lastly, the social organization of squirrel monkeys S. oerstedii in Costa Rica is markedly distinct (Boinski, in press). Squirrel monkey troops in South America always exhibit strong dominance hierarchies and high levels of aggression. Costa Rican squirrel monkeys, however, arguably exhibit the most egalitarian, least aggressive social organization of any primate taxon with typically large troops; neither males nor females can be described as 'dominant' over the other sex.

Distinctive features of the natural history of Central American squirrel monkeys enhance their susceptiblility to local extinction (Boinski 1987b, 1988, 1989; Boinski and Fowler, 1989; Boinski and Sirot, 1997; Wong, 1990b).

1 In continuous forest, Central American squirrel monkeys have large troop sizes (40-70) and large annual ranges (>2 sq km). Long-term monitoring of isolated populations indicates that local extinction is almost certain when a group contains fewer than 15 members and less than c. 30 ha available habitat (Boinski and Sirot, 1997).

2 Travel routes, and thus the habitat areas that can be exploited, have stringent requirements and are readily abandoned. Central American squirrel monkeys travel and forage almost exclusively on branches between 1-2 $\mathrm{cm}$ in diameter and seldom make horizontal leaps greater than $2 \mathrm{~m}$. Moreover, travel or any activity on the ground is extremely rare. As a consequence, road cuts, clearings for telephone and electric power lines, or even primary forests with gaps between tree canopies 


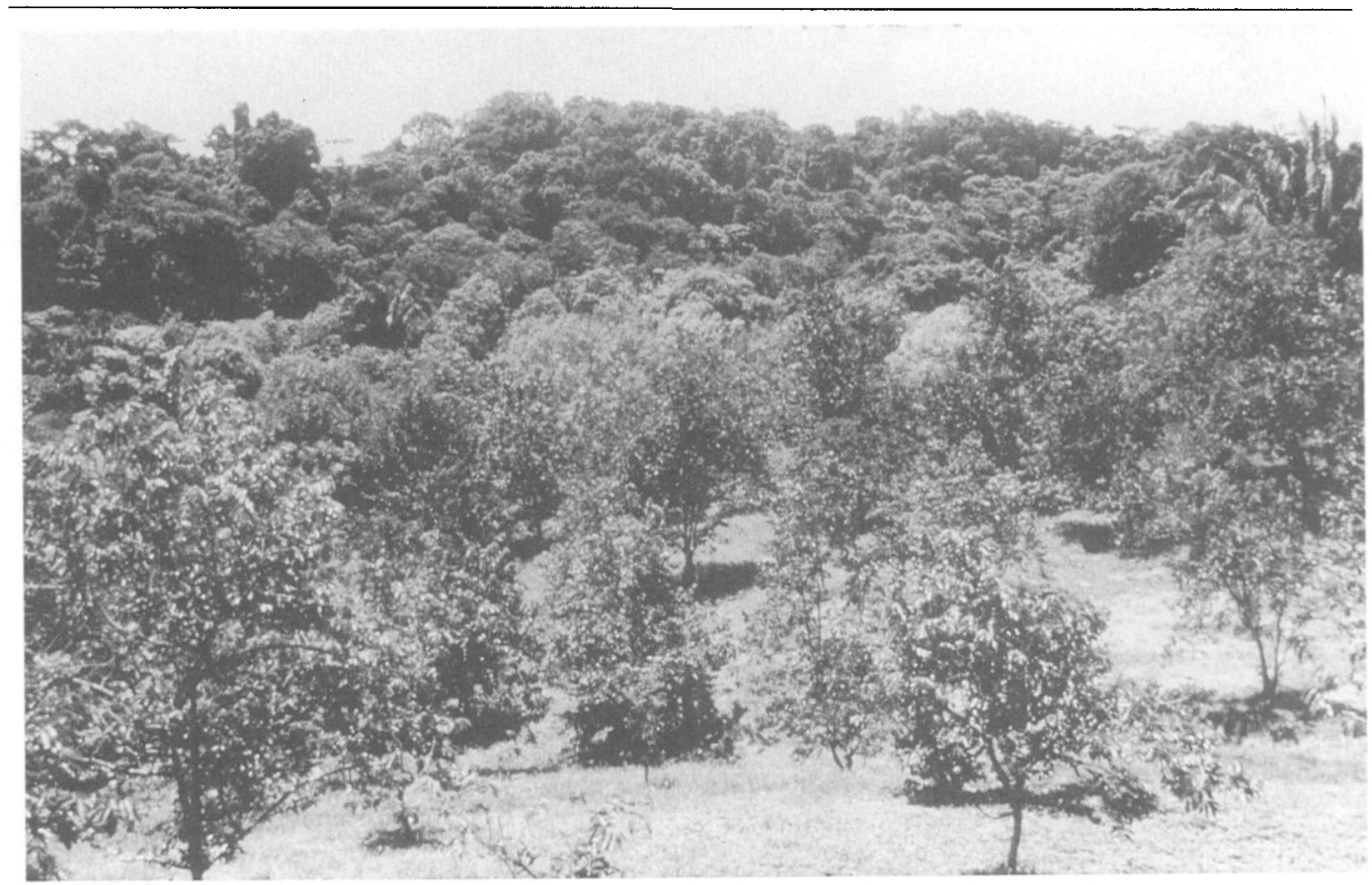

Figure 3. A typical example of the early successional habitat on which Costa Rican squirrel monkeys are now heavily dependent: an overgrown pasture adjacent to a heavily disturbed secondary forest on the Burica Peninsula (Katharine Jack).

and little understorey can severely circumscribe troop movements.

3 The diet of Central American squirrel monkeys consists largely of phytophagous arthropods (Orthoptera such as grasshoppers and katydids, and lepidopterous caterpillars), and small berry-like fruits (and cultivated guava, banana, mango and cacao when little else is available). Disturbed and early successional habitats are clearly preferred to primary forest. This is because regenerating forest, compared with primary forest, generally has a greater abundance of phytophagous arthropods, fruits and flowers (Figure 3). Therefore, squirrel monkeys are extremely vulnerable to habitat succession. Parts of Costa Rican protected areas, such as the Llorona plateau of Parque Nacional Corcovado, in which secondary habitat was allowed to follow its typical course of regeneration, have experienced local extinction of squirrel monkeys. Yet successional habitat created by human settlements, although more abundant than primary forest, is seldom beneficial because squirrel monkeys exploiting these areas become agricultural pests and vulnerable to a panoply of risks unique to this habitat (see below).

4 Central American squirrel monkeys are documented to suffer severe food stress during the annual rainy season. The Pacific wet lowland region of Costa Rica has extremely pronounced seasonal fluctuations in rainfall, with negligible rain from January to March but an intense rainy season from August to November, when arthropod abundance declines dramatically. Moreover, the availability of the small berry-like fruits that squirrel monkeys specialize in harvesting is also at the annual nadir. As a result, squirrel monkeys greatly expand their ranging areas and virtually every moment of diurnal activity is allocated to searching for food. Not surprisingly, the physical condition of squirrel monkeys visibly declines during the rainy season. The minimum habitat required to sustain a troop over the long term is undoubtedly best 


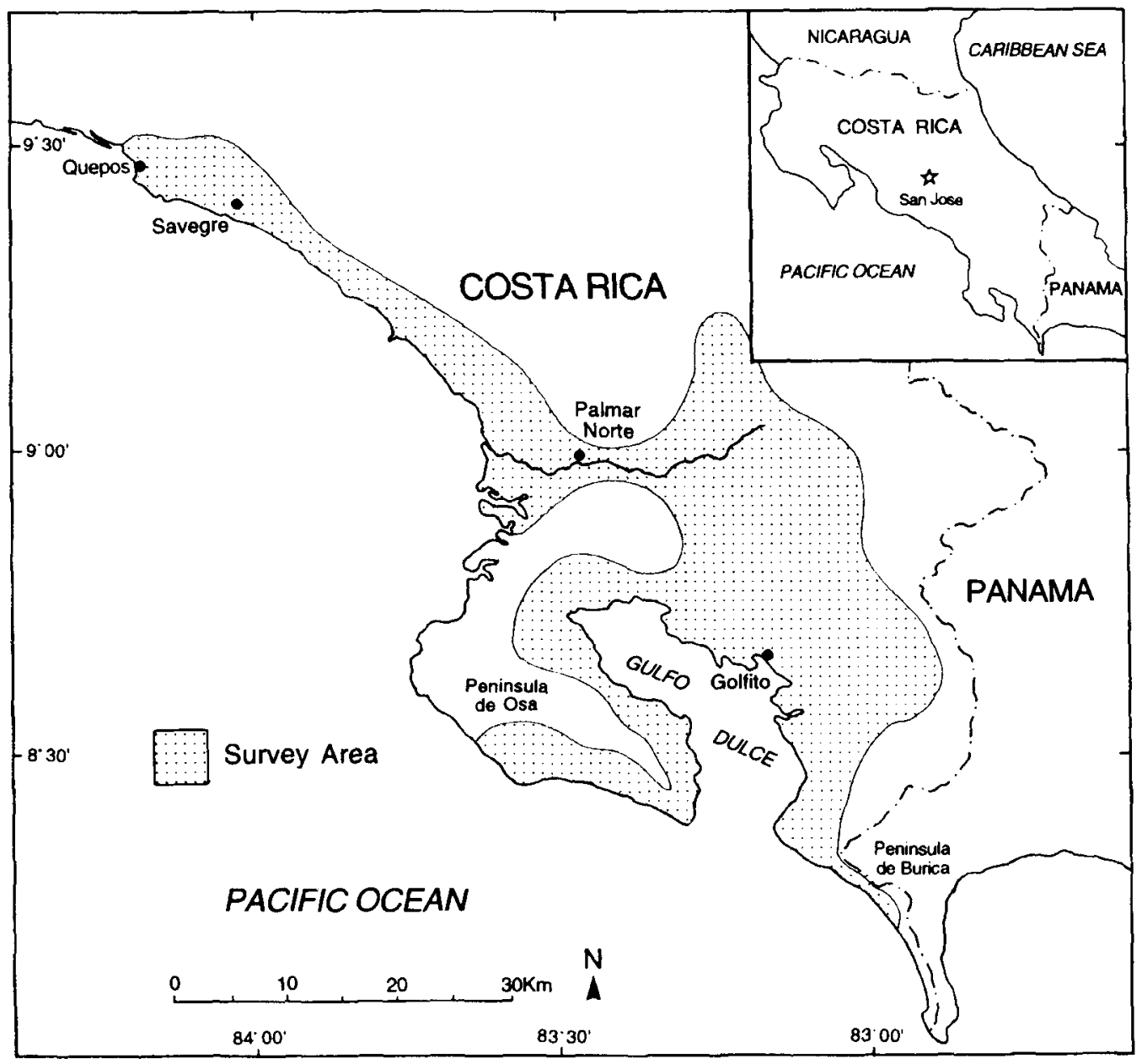

Figure 4. Area of the Pacific wet lowlands of Costa Rica surveyed for this report

represf ated by the extent of its habitat needs during the rainy season.

\section{Methods}

The primary objective of our study was to document Costa Rican localities where squirrel monkey troops still survived. Figure 4 indicates the the areas surveyed for this report. Published information on definite or possible populations, in addition to extensive interviews with knowledgeable informants were collated immediately prior to the initiation of the survey (see also Map 1 in Boinski and (ㄷ) $1998 \mathrm{FFI}$, Oryx, 32 (1), 45-58
Sirot, 1997). This collation determined the maximum limits of the surveyed area and the areas targeted as likely to contain squirrel monkeys but for which no recent and definite proof was available. Most sites were visited by three to four fieldworkers, the exceptions being Parque Nacional Corcovado and adjacent sites, which were visited by one field worker. In the course of our travels in the Pacific wet lowlands of Costa Rica we also searched for any unreported forested habitat that might contain squirrel monkeys. The only area we excluded from our survey was a zone of approximately $150 \mathrm{sq} \mathrm{km}$, between Quepos $\left(9^{\circ} 24^{\prime} \mathrm{N} 84^{\circ} 10 \mathrm{E}\right)$ and Parrita $\left(9^{\circ} 32 \mathrm{~N} 84^{\circ} 18^{\prime} \mathrm{E}\right)$, 


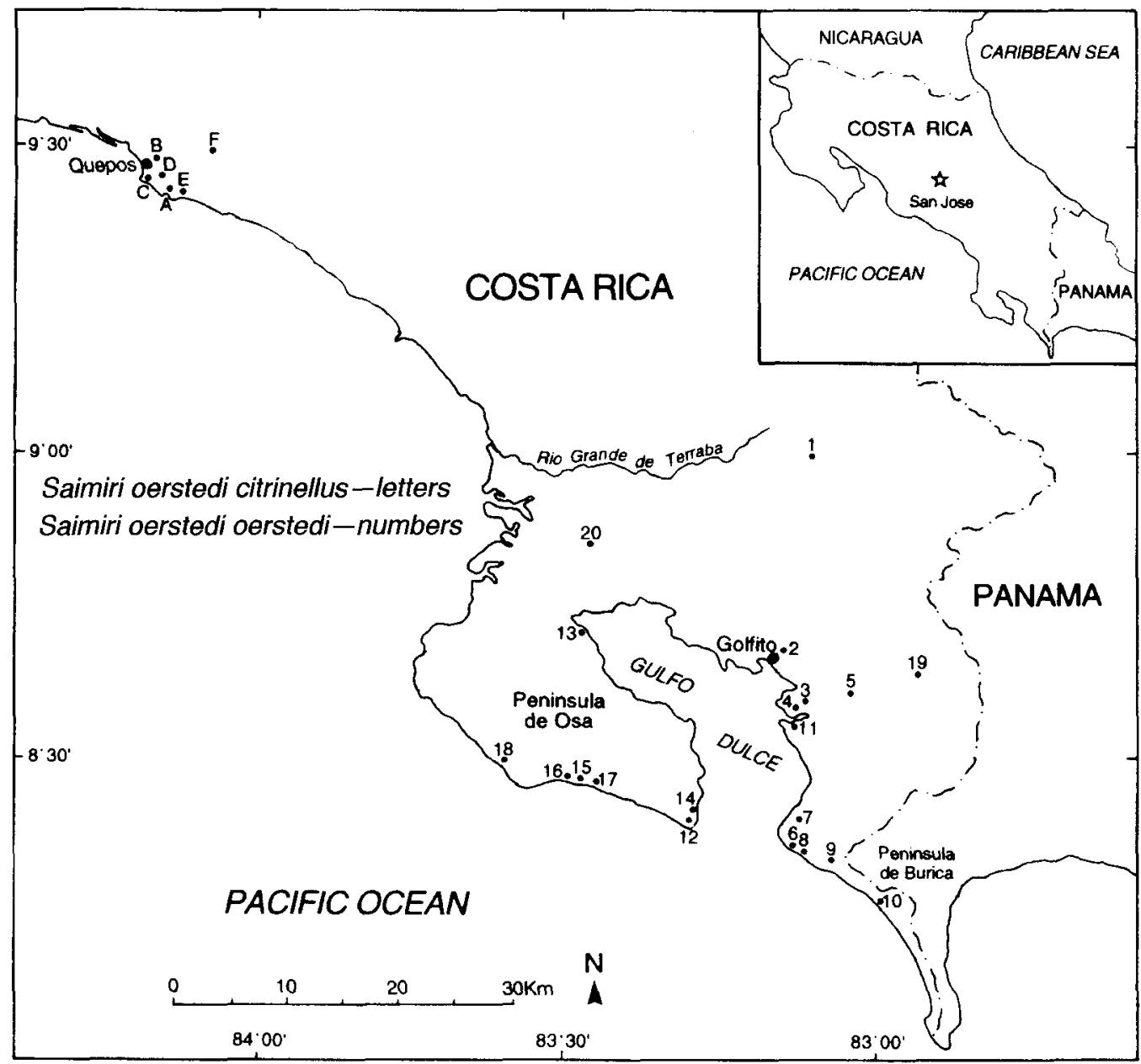

Figure 5. A map of the confirmed localities for remaining populations of both subspecies of Costa Rican squirrel monkeys. Historical records indicate that the Rio Grande de Térraba was formerly the boundary separating S. o. citrinellus to the north of the river and S. o. oerstedii to the south.

representing the most northern area in which squirrel monkeys (S. o. citrinellus) have occurred in historical knowledge. Wildlife biologists from the Programa Regional en Manejo de Vida Silvestre of the Universidad Nacional in Heredia, Costa Rica were completing a survey for S.o.citrinellus in that zone just as our survey began (Altrichter et al., 1996).

Once a known or potential squirrel monkey locality was reached several techniques were employed to track and locate squirrel monkeys in site transects. For transects we followed compass bearings through forested areas (trail construction being neither feasible nor desirable), as well as exploiting stream beds, extant trails and roads. Approximately 4 $h$ per day were spent surveying in the field, concentrated in the morning and late afternoon, when squirrel monkeys are most active and readily detected (Boinski and Sirot, 1997). Other daylight hours were allocated to travelling between sites and interviewing informants. Localities and areas surveyed were considered 'unlikely' or 'impossible' to contain squirrel monkeys when they were effectively denuded of trees and shrubs or 
consisted of large, continuous plantations of trees, such as oil palm Elais guaianensis, known not to provide significant food resources to squirrel monkeys. When squirrel monkeys were encountered, as much information as possible was recorded on troop size, age-sex composition, foraging behaviour, habitat use, social and vocal behaviour. Whether or not squirrel monkeys were found, we investigated current and former threats to this species at each site.

\section{Confirmed localities}

Here we report only those Costa Rican localities in which the presence of squirrel monkeys was visually confirmed. Our 1996 survey established that squirrel monkeys were present at a minimum of 26 localities in Costa Rica, six with S. o. citrinellus and 20 with S.o. oerstedii (Table 1, Figure 5). These localities are often so distant from the nearest other locality (mean 3.6 $\pm 1.1 \mathrm{SE} \mathrm{km}, n=26$ ), compounded by the absence of intervening forest corridors, that dispersal of squirrel monkeys between localities is extremely unlikely. Even troops within $1 \mathrm{~km}$ of the range of another troop commonly face a gauntlet of challenges to dispersal (see below). We found 284 S. o. citrinellus and 962 S. o. oerstedii individuals. Twentyfive squirrel monkeys per troop was used as a conservative estimate of troop size for 10 troops of S. o. oerstedii in which exact counts were not achieved. For example, only a cluster of three adult males was sighted at both Puerto Escondito and Finca San Gerardo (Table 1; Figure 5, key labels 13 and 19). Because adult males in poorly habituated Saimiri oerstedii troops often approach human observers and other potentially dangerous intruders while other troop members flee, an apparent defense strategy (Boinski, unpubl. data; Boinski and Mitchell, 1994), these small groups of males indicated the presence of a troop at the site.

A small proportion of the squirrel monkeys recorded was located within three protected areas: (i) Parque Nacional Manuel Antonio, 683 ha, with 105 S. o. citrinellus; (ii) Parque
Nacional Corcovado, 41,789 ha, with a minimum of 200 S. o. oerstedii, and (iii) Refugio Nacional de Fauna Silvestre, 2830 ha, with at least one troop of 58 S. o. oerstedii. Much of the habitat in all three protected areas is primary or high-grade forest and thus rarely exploited by squirrel monkeys. All other reported localities are on private and otherwise unprotected lands. The largest surviving and least disturbed breeding population of either subspecies is undoubtedly that in Parque Nacional Corcovado. It is possible that current numbers may be higher than the 200 monkeys we counted because the population in this park in 1984 was estimated to be $400-500$ based on 3 years of field work resulting in 10 individually distinguished troops (Boinski, 1985; Boinski and Sirot, 1997).

Our survey almost certainly missed some sites with squirrel monkeys and, with the exception of the 105 S. o. citrinellus in Parque Nacional Manuel Antonio, probably undercounted the number of individuals at some of the sites where squirrel monkeys were found. However, we are reasonably confident that no locality with large numbers $(>100)$ of squirrel monkeys remains unidentified in the area we surveyed. The most likely portion of Costa Rica in which undocumented troops may remain in our survey area are valley bottoms in the vicinity of the village of Coto Brus $\left(8^{\circ} 58^{\prime} \mathrm{N}\right.$, $83^{\circ} 06^{\prime} \mathrm{E}$; Table 1, Figure 5, key label 1). There we found a single troop in an isolated patch of riverine forest, and squirrel monkeys may also inhabit other relict forest patches in this extensive, although heavily deforested, valley system. Several inaccessible patches of forest in the southernmost tip of the Burica Peninsula also warrant further scrutiny .

It should be noted that approximately 20 isolated groups totalling 445 individual (397 adult) S. o. citrinellus were identified by the Universidad Nacional survey between Quepos and Parrita (Altrichter et al., 1996).

\section{Current threats}

The situation in Panama foreshadows the future of Costa Rican squirrel monkeys. Squirrel 
Table 1. Confirmed squirrel monkey localities in Costa Rica

\begin{tabular}{|c|c|c|c|c|c|c|}
\hline \multicolumn{2}{|c|}{$\begin{array}{l}\text { Location, key } \\
\text { label and name }\end{array}$} & $\begin{array}{l}\text { Sub- } \\
\text { species* }\end{array}$ & \multirow{2}{*}{$\begin{array}{l}\text { Min. count } \\
\text { of troop(s) }\end{array}$} & \multirow{2}{*}{$\begin{array}{l}\begin{array}{l}\text { Latitude/ } \\
\text { longitude }\end{array} \\
9^{\circ} 23.5^{\prime}, 84^{\circ} 08^{\prime}\end{array}$} & \multirow{2}{*}{$\begin{array}{l}\text { Major } \\
\text { threatst } \\
\text { DT, F }\end{array}$} & \multirow[b]{2}{*}{$\begin{array}{l}\text { Comments } \\
\text { Hurricane in } 1992 \text { levelled } \\
\text { c. } 25 \text { per cent of } 5-\mathrm{sq}-\mathrm{km} \\
\text { reserve. These areas are now } \\
\text { prime squirrel monkey } \\
\text { habitat. This absolute } \\
\text { population count is less than } \\
\text { one half of some previous } \\
\text { estimates. }\end{array}$} \\
\hline A & $\begin{array}{l}\text { Parque Nacional } \\
\text { Manuel Antonio }\end{array}$ & $\begin{array}{l}\text { In June } 1996 \\
\text { only these } 3 \\
\text { troops }(n=105) \\
\text { ranged in } \\
\text { this reserve. }\end{array}$ & & & & \\
\hline $\mathrm{B}$ & $\begin{array}{l}\text { Reserva Biologica, } \\
\text { Manuel Antonio }\end{array}$ & Soc & 30 & $9^{\circ} 25^{\prime}, 84^{\circ} 09^{\prime}$ & $\begin{array}{l}\text { DA, DT, } \\
\text { F }\end{array}$ & \\
\hline $\mathrm{C}$ & $\begin{array}{l}\text { Mariposa Hotel, } \\
\text { Manuel Antonio }\end{array}$ & Soc & 45 & $9^{\circ} 24^{\prime}, 84^{\circ} 10^{\prime}$ & $\mathrm{DT}, \mathrm{F}$ & $\begin{array}{l}\text { Three } S . \text { o. oerstedii adult } \\
\text { females were photographed } \\
\text { carrying oerstedii } \times \text { citrinellus } \\
\text { hybrid infants. }\end{array}$ \\
\hline $\mathrm{D}$ & $\begin{array}{l}\text { Jardin Gaia, } \\
\text { Manuel Antonio }\end{array}$ & Soc & $\begin{array}{l}24 \\
20\end{array}$ & $\begin{array}{l}9^{\circ} 24.5^{\prime} \\
84^{\circ} 08.5^{\prime}\end{array}$ & $\begin{array}{l}\mathrm{DA}, \mathrm{DT}, \\
\mathrm{F}\end{array}$ & $\begin{array}{l}\text { Two S. o. oerstedii adult } \\
\text { females were photographed } \\
\text { carrying oerstedii } \times \text { citronellus } \\
\text { hybrid infants. This and } \\
\text { sightings above imply that } \\
\text { at least five adult females of } \\
\text { S. o. oerstedii were released } \\
\text { in vicinity of Manuel } \\
\text { Antonio in previous years. }\end{array}$ \\
\hline $\mathrm{E}$ & $\begin{array}{l}\text { Boca del Río } \\
\text { Naranjo }\end{array}$ & Soc & 25 & $9^{\circ} 22.5^{\prime}, 84^{\circ} 06^{\prime}$ & DA, F, P & $\begin{array}{l}\text { Monkeys travel through } \\
\text { palm plantations to reach } \\
\text { forest patches. }\end{array}$ \\
\hline $\mathrm{F}$ & $\begin{array}{l}\text { La Botanica, } \\
\text { Londres }\end{array}$ & Soc & 35 & $9^{\circ} 30^{\prime}, 84^{\circ} 03^{\prime}$ & $\mathrm{D}, \mathrm{F}$ & $\begin{array}{l}\text { A planned dam may } \\
\text { jeopardize remaining } \\
\text { troops. }\end{array}$ \\
\hline 1 & $\begin{array}{l}\text { Coto Brus } \\
\text { system }\end{array}$ & Soo & 25 & $8^{\circ} 58^{\prime}, 83^{\circ} 06^{\prime}$ & $\mathrm{D}, \mathrm{F}$ & $\begin{array}{l}\text { Monkeys in this valley } \\
\text { rely on relict large trees } \\
\text { adjacent to the rivers as } \\
\text { travel routes. The high } \\
\text { elevations of valley walls } \\
\text { restrict group movements } \\
\text { out of the valleys. }\end{array}$ \\
\hline 2 & $\begin{array}{l}\text { Refugio Nacional } \\
\text { de Fauna Silvestre, } \\
\text { Golfito }\end{array}$ & Soo & 58 & $8^{\circ} 39^{\prime}, 83^{\circ} 09.5^{\prime}$ & $\mathrm{D}, \mathrm{F}, \mathrm{H}$ & $\begin{array}{l}\text { This reserve is cut off from } \\
\text { populations of monkeys to } \\
\text { the south by major roads. }\end{array}$ \\
\hline 3 & Esperanza & Soo & 31 & $8^{\circ} 34^{\prime}, 83^{\circ} 06^{\prime}$ & $\mathrm{DA}, \mathrm{F}$ & $\begin{array}{l}\text { Habitat fragmented by } \\
\text { roads, rivers, agriculture. }\end{array}$ \\
\hline 4 & Bajo de Coto & Soo & 28 & $8^{\circ} 34^{\prime}, 83^{\circ} 07^{\prime}$ & $\mathrm{DA}, \mathrm{F}$ & $\begin{array}{l}\text { Habitat fragmented by } \\
\text { roads, rivers, agriculture. }\end{array}$ \\
\hline 5 & $\begin{array}{l}\text { Bajo Grapa (Finca } \\
\text { de David } \\
\text { Olovorado } \\
\text { Zomora) }\end{array}$ & Soo & 25 & $8^{\circ} 34.5^{\prime}, 83^{\circ} 03^{\prime}$ & $\mathrm{DA}, \mathrm{F}$ & $\begin{array}{l}\text { Habitat fragmented by } \\
\text { roads, rivers, agriculture. }\end{array}$ \\
\hline 6 & $\begin{array}{l}\text { Tiskita Lodge, } \\
\text { Punta Banco }\end{array}$ & Soo & $\begin{array}{l}35 \\
25\end{array}$ & $\begin{array}{l}8^{\circ} 23.5^{\prime} \\
83^{\circ} 08.5^{\prime}\end{array}$ & $\begin{array}{l}\text { DA, DT, } \\
P, S\end{array}$ & $\begin{array}{l}\text { Tourism developing. Palm } \\
\text { and Gmelina plantations } \\
\text { encroaching from the north. }\end{array}$ \\
\hline
\end{tabular}


Table 1. Confirmed squirrel monkey localities in Costa Rica (continued)

\begin{tabular}{|c|c|c|c|c|c|c|}
\hline \multicolumn{2}{|c|}{$\begin{array}{l}\text { Location, key } \\
\text { label and name }\end{array}$} & \multirow{2}{*}{$\begin{array}{l}\begin{array}{l}\text { Sub- } \\
\text { species* }\end{array} \\
\text { Soo }\end{array}$} & \multirow{2}{*}{$\begin{array}{l}\text { Min. count } \\
\text { of troop(s) }\end{array}$} & \multirow{2}{*}{$\begin{array}{l}\begin{array}{l}\text { Latitude/ } \\
\text { longitude }\end{array} \\
8^{\circ} 24^{\prime}, 83^{\circ} 07.5^{\prime}\end{array}$} & \multirow{2}{*}{$\begin{array}{l}\begin{array}{l}\text { Major } \\
\text { threatst }\end{array} \\
\begin{array}{l}\text { DA, DT, } \\
\text { P,S }\end{array}\end{array}$} & \multirow{2}{*}{$\begin{array}{l}\text { Comments } \\
\text { Tourism developing. Palm } \\
\text { and Gmelina plantations } \\
\text { encroaching from the north. }\end{array}$} \\
\hline 7 & $\begin{array}{l}\text { Pavones (Finca de } \\
\text { Laura Alvarado } \\
\text { Gomez) }\end{array}$ & & & & & \\
\hline 8 & $\begin{array}{l}\text { Punta Banco, } \\
\text { Burica Peninsula }\end{array}$ & Soo & $\begin{array}{l}\text { ( } 2 \text { troops) } \\
50 \S\end{array}$ & $8^{\circ} 21^{\prime}, 83^{\circ} 06.5^{\prime}$ & $\mathrm{CH}, \mathrm{D}$ & \\
\hline 9 & $\begin{array}{l}\text { La Penita, Burica } \\
\text { Peninsula }\end{array}$ & Soo & $\begin{array}{l}(1 \text { troop }) \\
25 \S\end{array}$ & $8^{\circ} 19^{\prime}, 83^{\circ} 04^{\prime}$ & $\begin{array}{l}\mathrm{CH}, \mathrm{D}, \\
\mathrm{F}\end{array}$ & \\
\hline 10 & $\begin{array}{l}\text { Clarita, Burica } \\
\text { Peninsula }\end{array}$ & Soo & 38 & $8^{\circ} 16^{\prime}, 82^{\circ} 58^{\prime}$ & $\begin{array}{l}\mathrm{CH}, \mathrm{D}, \\
\mathrm{F}\end{array}$ & \\
\hline 11 & Playa Zancudo & Soo & $\begin{array}{l}(2 \text { troops }) \\
50 \S\end{array}$ & $8^{\circ} 33^{\prime}, 83^{\circ} 08^{\prime}$ & $\begin{array}{l}\text { CH, DA, } \\
\text { DT, F, S }\end{array}$ & $\begin{array}{l}\text { Gmelina plantations most } \\
\text { immediate threat. }\end{array}$ \\
\hline 12 & $\begin{array}{l}\text { Matapalo, Bosque } \\
\text { del Cabo, Osa } \\
\text { Peninsula }\end{array}$ & Soo & $\begin{array}{l}20 \\
22\end{array}$ & $8^{\circ} 22^{\prime}, 83^{\circ} 18^{\prime}$ & $\mathrm{DA}, \mathrm{F}$ & \\
\hline 13 & $\begin{array}{l}\text { Puerto Escondito, } \\
\text { Osa Peninsula }\end{array}$ & Soo & $\begin{array}{l}\text { ( } 3 \text { males } \\
\text { probably } \\
\text { defensive } \\
\text { sub-group } \\
\text { of troop) } 25 \$\end{array}$ & $8^{\circ} 40.5^{\prime}, 83^{\circ} 27^{\prime}$ & $\mathrm{DA}, \mathrm{F}$ & \\
\hline 14 & $\begin{array}{l}\text { Lapas Rios, Osa } \\
\text { Peninsula }\end{array}$ & Soo & $\begin{array}{l}(1 \text { troop }) \\
25 \S\end{array}$ & $8^{\circ} 24^{\prime}, 83^{\circ} 17^{\prime}$ & $\mathrm{D}, \mathrm{F}$ & \\
\hline 15 & $\begin{array}{l}\text { Between Agua } \\
\text { Buena and Carate }\end{array}$ & Soo & $\begin{array}{l}2 \text { troops } \\
\text { totalling } \\
\text { approx. } \\
100 \text { inds. }\end{array}$ & $8^{\circ} 26^{\prime}, 83^{\circ} 25^{\prime}$ & $\mathrm{D}, \mathrm{F}$ & \\
\hline 16 & $\begin{array}{l}\text { Carate, Osa } \\
\text { Peninsula }\end{array}$ & Soo & $\begin{array}{l}(1 \text { troop }) \\
25 \S\end{array}$ & $8^{\circ} 27^{\prime}, 83^{\circ} 27^{\prime}$ & $\mathrm{D}, \mathrm{F}$ & \\
\hline 17 & $\begin{array}{l}\text { Agua Buena, Osa } \\
\text { Peninsula }\end{array}$ & Soo & $\begin{array}{l}\text { (1 troop) } \\
25 \S\end{array}$ & $8^{\circ} 26^{\prime}, 83^{\circ} 24^{\prime}$ & & \\
\hline 18 & $\begin{array}{l}\text { Parque Nacional } \\
\text { Corcovado, Osa } \\
\text { Peninsula }\end{array}$ & Soo & $\begin{array}{l}\text { Min. of } \\
5 \text { troops, } \\
\text { each with } \\
40 \text { members, } \\
N \geq 200\end{array}$ & $\begin{array}{l}\text { Between } \\
8^{\circ} 27^{\prime} \text { and } 8^{\circ} 32^{\prime} \\
\text { and } \\
83^{\circ} 31^{\prime} \text { and } \\
83^{\circ} 39^{\prime}\end{array}$ & $\mathrm{H}$ & \\
\hline 19 & $\begin{array}{l}\text { Finca San } \\
\text { Gerardo (Sr } \\
\text { Ramon Cabezas) }\end{array}$ & Soo & $\begin{array}{l}\text { ( } 3 \text { males, } \\
\text { probably } \\
\text { defensive } \\
\text { subgroup } \\
\text { of troop) } \\
25 \S\end{array}$ & $8^{\circ} 34.5^{\prime}, 82^{\circ} 53^{\prime}$ & $\mathrm{D}, \mathrm{DA}, \mathrm{F}$ & $\begin{array}{l}\text { Installation of power lines } \\
\text { have destroyed and } \\
\text { fragmented the limited } \\
\text { remaining habitat. }\end{array}$ \\
\hline 20 & Sierpe & Soo & 20 & $8^{\circ} 52.5^{\prime}, 83^{\circ} 29^{\prime}$ & $\begin{array}{l}\text { DA, F, } \\
P, S\end{array}$ & $\begin{array}{l}\text { Banana, palm and Gmelina } \\
\text { plantations pose increasing } \\
\text { threats. Toxicity from } \\
\text { extensive pesticide use. }\end{array}$ \\
\hline
\end{tabular}

* Soc, Saimiri oerstedii citrinellus; Soo, S. o. oerstedii.

$+\mathrm{CH}$, capture for pets and hunting as crop pests; D, deforestation; DA, deforestation due to agriculture; DT, deforestation due to tourist development; F, habitat fragmentation; $\mathrm{H}$, habitat succession;

$P$, banana and oil palm plantations; $S$, silviculture.

$\S$ Estimated minimum group sizes (25 animals per troop) are given in instances when accurate counts could not be obtained. 
monkey populations in Costa Rica are decimated relative to historic levels. An optimistic estimate, based simply on doubling the approximate cumulative number of squirrel monkeys found by our survey and that of the Universidad Nacional team (Altrichter et al., 1996), is that a total of 1500 S. o. citrinellus and 2000 S. o. oerstedii survives in the wild or as near commensals to humans. In any case, the current effective population size of squirrel monkeys in Costa Rica is undoubtedly below the 5000 individuals that Lande (1995) calculates are needed to avoid inbreeding depression and maintain long-term genetic viability in a species. This pessimistic prognosis is only exacerbated when the genetic fragmentation of the remaining squirrel monkeys in Costa Rica is considered; Lande's estimation is premised on an assumption of random mating across a population. Our educated guess is that if the current development regime in Costa Rica continues unimpeded, in 15 years squirrel monkeys will survive at no more than half, and probably fewer, of the localities this survey documented. In 50 years, the distribution map of Costa Rican squirrel monkeys may have only two localities indicated, Parques Nacionales Corcovado and Manuel Antonio.

Deforestation and habitat fragmentation are the primary causes of the present critical status of Costa Rican squirrel monkeys. Agriculture continues to erode squirrel monkey habitat at the level of both agribusiness and the individual small farmer. Development for tourism is perhaps a less appreciated, but no less important, threat, especially for S.o. citrinellus in the vicinity of Quepos and Parque Nacional Manuel Antonio. Tourists and squirrel monkeys alike have strong habitat preferences for beachfront and lowland forests. With tourists come roads, restaurants, hotels, stores, and electric and telephone lines, all of which fragment and isolate squirrel monkey populations. The clearing of forest and scrub along the routes of power lines has led to electrocution being arguably the major source of direct mortality for $S . O$. citrinellus, and a significant one for S. o. oerstedii. Squirrel monkeys use power lines for travel routes when thin arboreal branches are unavailable and at many sites power lines are the only nonterrestrial connections among discontinuous ranging areas (Figure 6). Despite this apparently positive feature, insulation on the power lines is poor and the electrocution of squirrel monkeys and other arboreal mammals is common (Figure 7; Boinski and Sirot, 1997).

Plantations and silviculture are threats meriting mention apart from agricultural development because of the huge expanse of former squirrel monkey habitat they now occupy. As far as we could determine, effectively all of the lowland coastal area (550 sq $\mathrm{km}$ ) between Savegre and Palmar Norte (Figure 4), formerly prime S. o. citrinellus habitat (Boinski 1987b), is now converted to oil palm plantations and human settlements. Patchier, but still extensive oil palm and banana plantations are also a significant landscape component in the range of S. o. oerstedii to the south.

A recent incursion on S. o. oerstedii habitat around the Golfo Dulce and Burica Peninsula is the establishment in the past decade of plantations totalling at least 14,000 ha of Gmelina arborea, a fast-growing tree native to India, by Stone Container Corporation of the United States. Gmelina is planted in pastures and other previously cleared areas as monoculture stands, which are regularly sprayed with pesticide, cleared of undergrowth and harvested for wood pulp after 8 years. Squirrel monkeys do not eat its fruit and have not yet been observed to forage for whatever arthropod fauna might survive the pesticide applications. From the perspective of squirrel monkeys this nominally 'empty' land was certainly either already prime habitat or would have quickly succeeded to the early successional habitat preferred by squirrel monkeys. On the other hand, plantations of Gmelina do provide transient benefits in that they allow squirrel monkey troops to travel between otherwise isolated patches of exploitable forest.

Other notable threats, albeit of reduced impact compared with deforestation and habitat fragmentation, include habitat succession, the pet trade, and hunting as crop pests. 
Figure 6. Squirrel monkey habitat within Parque Nacional Manuel Antonio is bisected by a road paralleled by a wide clearance for powerlines. $S$. $O$. citrinellus, such as these females with 2-month old infants, depend on the power lines as travel routes along and across the road (Sue Boinski).

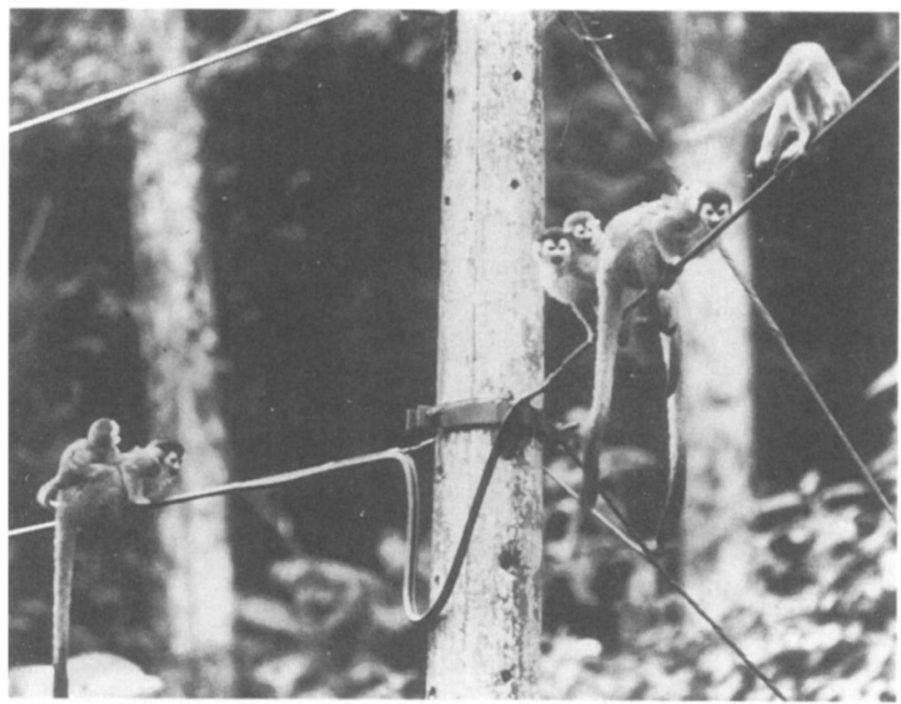

1 Squirrel monkeys are clearly at risk of losing further numbers in Parque Nacional Corcovado and the Refugio Nacional de Fauna Silvestre in Golfito as a result of succession of formerly extensive disturbed habitats. Fortuitously for the squirrel monkeys in Parque Nacional Manuel Antonio, a 1992 hurricane toppled approximately 25 per cent of the forest of this small protected area, and the areas of regenerating forest now provide more prime habitat for squirrel monkeys than was present before the hurricane.

2 A pet trade still exists where Boinski and Sirot (1997) predicted none. Ten pet squirrel monkeys were encountered during our survey, and five more were illegally on exhibit at a private zoological garden catering for tourists. At least 15 of the squirrel monkeys currently held in the two legal captive colonies (Jardin Gaia, a wildlife rehabilitation center in Manuel Antonio that is open to visitors, and a private colony on the outskirts of San José owned by Dr Ludwig Müller) are former pets. More illicit captives undoubtedly exist. Numerous informants independently reported that (a) the current price for a pet squirrel monkey was $\$$ US30-50, (b) pet squirrel monkeys were relatively easy to obtain, and, (c) animals were not infrequently smuggled out of the country. One restaurant between Quepos and Parque Nacional Manuel

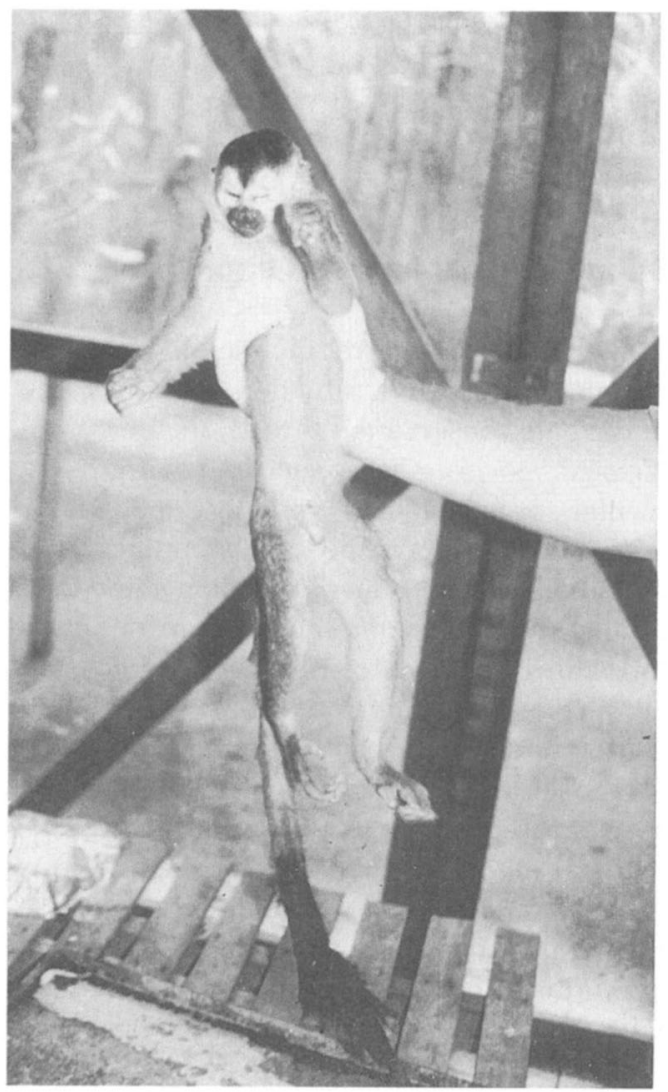

Figure 7. A dead adult male $S$. o. citrinellus electrocuted while traversing a power line about 2 $\mathrm{km}$. outside the Parque Nacional Manuel Antonio (Katharine Jack). 
Antonio has a commensal troop that forages on the patrons' tables and is also given food by restaurant staff to maintain the troop as a tourist attraction. We strongly suspect that the five adult female S. o. oerstedii we closely observed in the Quepos tourist developments surrounding Parque Nacional Manuel Antonio $(72 \mathrm{~km}$ up the Pacific coast from the closest point of this subspecies's documented range) were captives released in 1995.

3 Although we did not see hunting or carcasses, numerous local informants, especially in the vicinity of Quepos and on the Burica Peninsula, readily and independently described hunting as an effective deterrent to crop raiding. This is consistent with an upsurge of complaints of crop damage caused by squirrel monkeys harvesting garden produce compared with previous surveys (Boinski 1985, 1987a; Boinski and Sirot, 1997). As with the pet trade, hunting was previously thought to be a negligible risk (Boinski and Sirot, 1997).

\section{Suggested management strategies}

Each confirmed squirrel monkey locality represents a distinctive situation regarding the immediate conservation threats, the mix of interested government agencies, non-governmental organizations, private landowners, economic interests of the local community and potentially useful remedies. Under these conditions, a simple, comprehensive prescription for squirrel monkey conservation suitable for all sites is not attainable. In any case, broad conservation attempts for either all Costa Rican squirrel monkeys or one of the subspecies based largely on public education in the national media have been notably unsuccessful thus far. Therefore, we strongly advocate that future conservation efforts by concerned individuals, local groups and non-governmental organizations should target a single site or tight cluster of sites to secure and maintain a specific local population of squirrel monkeys. Perhaps a separate advocacy and support group could be recruited locally, nationally and internationally for each locality.
The basic arsenal of conservation measures for squirrel monkeys is not large, and each should be fitted to the circumstances of the specific locality.

1 Available forest must be protected from further deforestation and fragmentation. All parties making land-use decisions must be informed of the economic and ecological benefits of maintaining a local squirrel monkey population. Owners of land for vacation retreats and tourist lodges, in addition to tourism industry associations, should be particularly targeted for enlistment in conservation projects.

2 Second-growth and early successional habitat must be maintained. Nationally protected areas and privately owned forests should be managed, not merely 'protected'. Squirrel monkey habitat must contain a large component of secondary forest. Many of the plant genera that define early successional growth in Pacific lowland Costa Rica, including Cecropia, Piper, Miconia, Palicourea and Lycianthes, provide most of the fruit and arthropod components of the squirrel monkey diet. Food sources can be further augmented and stabilized across the annual cycle by planting and maintaining patches of guava trees Psidium guajava. During the wet season, the fruits of feral and cultivated guava trees probably are crucial sources of food in many of the remaining squirrel monkey localities.

3 Squirrel monkeys use existing corridors for crossing roads or moving between separated forest patches when they are available. In areas inhabitated by squirrel monkeys safe travel routes must be maintained or established. The removal of branches overhanging roads should be discouraged, as should unnecessary brush and tree clearance from roadsides, pastures and underneath powerlines. Along commonly used travel routes, ropes or other branch substitutes should be provided across roads and other relatively narrow clearings, and the junctures of powerlines should be insulated where electrocution is a risk.

4 Squirrel monkey numbers should be monitored within each locality at frequent intervals, at least four times annually. This is much easier than it appears at first glance. Costa 
Rican squirrel monkeys are highly conservative in their use of sleeping trees. Probably one or two alternative trees account for 90 per cent or more of trees used as sleeping sites. Once these sleeping sites are identified (sleeping trees are reasonably predictable as to location and other characteristics; Boinski, 1987b; Boinski and Sirot, 1997), observers can readily document local population levels by monitoring the trees at predawn and dusk.

5 Based on criteria presented in Kleiman (1996), reintroduction or translocation of squirrel monkey troops into areas in which they were previously extirpated is not warranted at this stage of Costa Rican squirrel monkey conservation. Furthermore, we argue that resources are much more effectively spent maintaining squirrel monkeys in localities where they are already present rather than in attempts to establish new populations in areas in which long term habitat suitability is uncertain.

6 Once population and habitat losses are controlled within each locality, attention should be given to maintaining genetic diversity. Female dispersal predominates among Costa Rican squirrel monkeys, and females readily change troops with no aggression from either resident male or female troop members (Boinski and Mitchell, 1994). Wildlife population geneticists should be consulted about the minimum transfer rate of females needed between isolated localities (Lande, 1995).

\section{Acknowledgements}

Ludwig Müller, Dario Castelfranco and Anne Simpson de Gamboa are foremost among the many who rendered patient assistance with the planning and implementation of this survey. Many Costa Ricans generously gave us their time, advice and permission to enter their properties. We thank the Dirección General de Vida Silvestre for permission to work in Costa Rican parks and preserves. A grant from the National Geographic Society to SB provided essential financial support for this survey. Colin Chapman, Margaret Kinnaird and Gary Steck thoughtfully commented on earlier versions of the manuscript.

\section{References}

Altrichter, M., Fernandez, M.T., Gomez, L.G., Gonzalez, J., Fernandez, C., Herrera, H. et al. 1996. Evaluación de la fragmentación del hábitat y estado del mono tití (Saimiri oerstedi citrinellus) en el Pacífico Central, Costa Rica. Programa Regional en Manejo de Vida Silvestre, Universidad Nacional, Heredia, Costa Rica.

Arauz, J. 1993. Estado de conservaçión del mono tití (Saimiri oerstedi citrinellus) en su area de distribucion original. Thesis de Grado, Escuela de Ciencias Ambientales, Universidad Nacional, Heredia, Costa Rica.

Boinski, S. 1985. Status of squirrel monkeys in Costa Rica. Primate Conservation, 6, 15-16.

Boinski, S. 1987a. The status of Saimiri oerstedi citrinellus in Costa Rica. Primate Conservation, $\mathbf{8}$, 69-72.

Boinski, S. $1987 \mathrm{~b}$. Habitat use in squirrel monkeys (Saimiri oerstedi) in Costa Rica. Folia primatologia, 49, 151-167.

Boinski, S. 1988. Sex differences in the foraging behavior of squirrel monkeys in a seasonal habitat. Behavioral Ecology and Sociobiology, 23, 177-186.

Boinski, S. 1989. The positional behaviour and substrate use of squirrel monkeys: ecological implications. Journal of Human Evolution, 18, 659-677.

Boinski, S. In press. Stress responses in primates: proximate mechanisms in the evolution of social organization. In Geographic Variation in Behavior: An Evolutionary Perspective (eds S. A. Foster and J. A. Endler). Oxford University Press, Oxford.

Boinski, S. and Fowler, N.L. 1989. Seasonal patterns in a tropical lowland forest. Biotropica, 21, 223-234.

Boinski, S. and Jacobs, S.C. 1997. Behavioral and mtDNA divergence in squirrel monkeys. American Journal of Physical Anthropology Supplement, 24, 78-79.

Boinski, S. and Mitchell, C.L. 1994. Male dispersal and association patterns in Costa Rican squirrel monkeys (Saimiri oerstedi). American journal of Primatology, 34, 157-170.

Boinski, S and Sirot, L. 1997. Uncertain conservation status of squirrel monkeys in Costa Rica, Saimiri oerstedi oerstedi and Saimiri oerstedi citrinellus. Folia primatologica, 68, 181-193.

Butterfield, R.P. 1994. Forestry in Costa Rica: status, research priorities, and the role of the La Selva Biological Station. In La Selva: Ecology and Natural History of a Neotropical Rainforest (eds L. A. McDade, K. S. Bawa, H. A. Hespenheid and G. S. Hartshorn), pp. 317-328. University of Chicago Press, Chicago.

Carrillo, E. and Vaughan, C. 1993. Costa Rica. In La Vida Silvestre de Mesoamerica: Diagnostico y Estrategia para su Conservacion (eds E. Carrillo and 
C. Vaughan), pp. 237-263. Editorial de la Universidad Nacional (EUNA), Heredia, Costa Rica.

Costello, R.K., Dickinson, C., Rosenberger, A.L., Boinski, S. and Szalay, F.S. 1993. A multidisciplinary approach to squirrel monkey (genus Saimiri) species taxonomy. In Species, Species Concepts, and Primate Evolution (eds W. Kimbel and L. Martin), pp. 177-237. Plenum Press, New York.

Fundación Ambio. 1993. Diversidad Biológica y Dessarrollo Sostenible. Euroamericana Ediciones (CR) SA, San José.

Hershkovitz, P. 1984. Taxonomy of squirrel monkeys genus Saimiri (Cebidae, Platyrrhini): a preliminary report with a description of a hitherto unnamed form. American Journal of Primatology, 6 , 257-312.

IUCN. 1996. 1996 IUCN Red List of Endangered Animals. IUCN, Gland, Switzerland.

Kleiman, D.G. 1996. Reintroduction programs. In Wild Mammals in Captivity (eds D. G. Kleiman, M. E. Allen, K. V. Thompson, S. Lumpkin and $\mathrm{H}$. Harris), pp. 297-305. University of Chicago Press, Chicago.

Lacy, R.C. 1993. VORTEX: a computer simulation model for population viability analysis. Wildlife Research, 20, 45-65.

Lande, R. 1995. Mutation and conservation. Conservation Biology, 9, 782-791.

Matamoros, Y. Wong, G. and Seal, U. (eds) 1996. Population and Habitat Viability Assessment Workshop for Saimiri oerstedi citrinellus. Final Report. Conservation Breeding Specialist Group (IUCN/SSC), Apple Valley, MN, USA.

Reid, W.V., Laird, S.A., Gamez, R., Sittenfeld, A., Janzen, D.H., Gollin, M.A. and Juma, C. (eds). 1994. La Prospección de la Biodiversidad: El Uso de los Recursos Genéticos para el Desarrollo Sostenible. Instituto Nacional de Biodiversidad, San José.

Rodriguez-Luna, E., Mittermeier, R., Rylands, A., Wong-Reyes, G., Carrillo, E., Matamoros, Y. et al. 1996. Hacia un plan de acción para los primates mesoamericanos. Neotropical Primates, 4 (suppl.), 119-132.

Rylands, A.B., Mittermeier, R.A. and Rodriguez Luna, E. 1995. A species list for the New World primates (Platyrrhini): distribution by country, endemism, and conservation status according to the Mace-Lande system. Neotropical Primates, 3 (suppl.), 113-164.

Vaughan, C. 1983. A report on dense forest habitat for endangered wildlife species in Costa Rica. Environmental Sciences School, National University, Heredia, Costa Rica.

Wong, G. 1990a. Uso del habitat, estimación de composicción y densidad poblacional del mono tití (Saimiri oerstedi citrinellus) en la zona de Manuel Antonio, Quepos, Costa Rica. Thesis de Grado, Escuela de Ciencias Ambientales, Universidad Nacional, Heredia, Costa Rica.

Wong, G. 1990b. Ecología del mono titi: Saimiri oerstedi citrinellus en el Parque Nacional Manuel Antonio, Costa Rica. Thesis de Grado, Escuela de Ciencias Ambientales, Universidad Nacional, Heredia, Costa Rica.

Wong, G., Matamoros, Y. and Seal, U. 1994. Population and Habitat Viability Assessment Workshop for Saimiri oerstedi citrinellus. Final Report. Conservation Breeding Specialist Group (IUCN/SSC), Apple Valley, MN, USA.

Sue Boinski, Department of Anthropology and Division of Comparative Medicine, 1350 Turlington Hall, PO Box 117305, University of Florida, Gainesville, FL 32611-7305, USA. E-mail: Boinski@nervm.nerdc.ufl.edu

Katharine Jack, Department of Anthropology, University of Alberta, Edmonton, Alberta, Canada T6G $2 \mathrm{H} 4$.

Craig Lamarsh, Department of Anthropology, University of Alberta, Edmonton, Alberta, Canada T6G $2 \mathrm{H} 4$.

Jessica A. Coltrane, Tropical Conservation and Development Program, Department of Wildlife and Range Sciences, University of Florida, Gainesville, FL 32611, USA.

Received 27 February 1997

Accepted 13 October 1997 